\title{
Cell-based immunotherapy of glioblastoma multiforme (Review)
}

\author{
IGOR BRYUKHOVETSKIY \\ Medical Center, School of Medicine, Far Eastern Federal University, Vladivostok 690091, Russia
}

Received December 15, 2021; Accepted February 10, 2022

DOI: $10.3892 / 01.2022 .13253$

\begin{abstract}
Glioblastoma multiforme (GBM) is the most aggressive and lethal primary glial brain tumor. It has an unfavorable prognosis and relatively ineffective treatment protocols, with the median survival of patients being $\sim 15$ months. Tumor resistance to treatment is associated with its cancer stem cells (CSCs). At present, there is no medication or technologies that have the ability to completely eradicate CSCs, and immunotherapy (IT) is only able to prolong the patient's life. The present review aimed to investigate systemic solutions for issues associated with immunosuppression, such as ineffective IT and the creation of optimal conditions for CSCs to fulfill their lethal potential. The present review also investigated the main methods involved in local immunosuppression treatment, and highlighted the associated disadvantages. In addition, novel treatment options and targets for the elimination and regulation of CSCs with adaptive and active IT are discussed. Antagonists of TGF- $\beta$ inhibitors, immune checkpoints and other targeted medication are also summarized. The role of normal hematopoietic stem cells (HSCs) in the mechanisms underlying systemic immune suppression development in cases of GBM is analyzed, and the potential reprogramming of HSCs during their interaction with cancer cells is discussed. Moreover, the present review emphasizes the importance of the aforementioned interactions in the development of immune tolerance and the inactivation of the immune system in neoplastic processes. The possibility of solving the problem of systemic immunosuppression during transplantation of donor HSCs is discussed.
\end{abstract}

\section{Contents}

1. Introduction

2. Summary on GBM

Correspondence to: Professor Igor Bryukhovetskiy, Medical Center, School of Medicine, Far Eastern Federal University, 10 Ajax Bay, Russky Island, Vladivostok 690091, Russia

E-mail: igbryukhovetskiy@gmail.com

Key words: glioblastoma multiforme, cancer stem cells, temozolomide, hematopoietic stem cells, immunotherapy, extracellular matrix, transforming growth factor- $\beta$
3. Treatment resistance factors

4. Immune privilege of the CNS

5. IT and CSC control

6. Adaptive IT

7. Active IT

8. IT and molecular-based therapy

9. HSCs and IT

10. Conclusion

\section{Introduction}

Glioblastoma multiforme (GBM) is the most aggressive and lethal primary brain tumor (1). Globally, it constitutes $>50 \%$ of all diagnosed glioma cases and $20 \%$ of all central nervous system (CNS) tumors. In Europe and North America, the frequency of GBM is 3-5 cases per 100,000 individuals, mostly affecting non-Hispanic males (2). Notably, the average age of affected patients is 62 years. The tumor is characterized by invasive growth, intensive angiogenesis and an unfavorable prognosis. When following a modern protocol of complex treatment, the median survival of patients is $\sim 15$ months $(1,3)$. GBM radiation resistance is attributed to plasticity and marked proliferation abilities of cancer stem cells (CSCs), which are the main catalyst of neoplastic processes. Irradiation and chemotherapy are unable to eliminate CSCs effectively (4); thus, development of fundamentally novel approaches to GBM treatment are required, and immunotherapy (IT) has great potential.

IT has demonstrated a high level of efficiency in treating hemoblastoses, melanomas, lung, prostate and bladder cancer (5). IT effectively damages CSCs, disrupts their interaction with local cellular microsurroundings and the extracellular matrix (ECM), and controls further actions of CSCs, such as inhibiting the interaction between non-tumor cells and CSCs, thereby suppressing tumor progression and prolonging the patients' life. However, unlike other cancer types, GBM is protected from direct interaction with the immune system by the blood-brain barrier $(5,6)$. GBM cells do not express numerous unique antigens, create immunosuppressive microsurroundings, and express anti-inflammatory cytokines and inhibitors of the immune checkpoint (6), thereby affecting the immune response. The ability of these cells to suppress the immune system locally classifies GBM as a 'cold' tumor that is almost completely resistant to IT.

On the other hand, high radiation doses and chemotherapy inevitably cause myelosuppression (7), followed by severe 
systemic immunodeficiency (8) that is intensified by glucocorticosteroids (9), which are used for preventing cerebral edema during all stages of GBM treatment. A combination of local and systemic immunosuppression limits the antitumor potential of IT, and interferes with its ability to control CSCs (7-9). Thus, a novel systemic approach to GBM treatment is required, that combines classic methods of antitumor therapy, IT and innovative biomedical technologies that would be aimed at overcoming local and systemic immunosuppression.

The present study aimed to review systemic solutions for the issues associated with immunosuppression that interfere with the antitumor potential of cell-based IT used in patients with GBM.

\section{Summary on GBM}

The majority of patients with GBM require surgery to achieve brain decompression, minimize hydrocephalus and lower the risk of fatal complications (10). Using microsurgical equipment, modern neuro-navigation and intra-operative neuro-monitoring increases the chances of effective tumor removal, and minimizes the risk of damaging key functioning areas of the brain (11). However, GBM eradication via surgery is not possible due to brain tissue infiltration with cancer cells; therefore, the main treatment focus is chemoradiotherapy (12).

Traditionally, $\gamma$-radiation of $60 \mathrm{~Gy}$ is used, including 2 Gy daily at 30 fractions for 6 weeks (13), together with chemotherapy, where temozolomide (TMZ) is considered the gold standard for the treatment of GBM. Treatment options may be extended by combining $\gamma$-radiation with proton (14) or boron neutron capture therapy (15), the use of hyperbaric oxygen therapy, consuming a ketogenic diet or pharmacological support with Olaparib (16), kynurenine pathway metabolites (17) or other inducers of genomic instability (18). Tumor-treating fields increase the treatment effect $(11,19)$ and improve the patient's condition.

Current treatment options for GBM are relatively ineffective. In the majority of cases, despite the efforts of medical experts, tumor relapse occurs in 4-6 months following removal (20). In the case of recurrent GBM, patients with $\sim 70$ on the Karnofsky Performance Scale and 0-1 on the Eastern Cooperative Oncology Group scale may be reoperated (21). Further rounds of irradiation are rarely used; however, brachytherapy and radiosurgery are considered promising options (22). Chemotherapy may help extend a patient's life, and TMZ or lomustine are often used with bevacizumab (23). Treatment with procarbazine, lomustine, vincristine and platinum-based medications (24) remain limited. Best supportive care is recommended for all patients with recurrent GBM, as the associated prognosis is unfavorable, and the median survival is $\sim 15$ months (25) due to the coordinated combination of local factors and systemic mechanisms.

\section{Treatment resistance factors}

At the genomic level (26), treatment resistance is caused by a unique range of genetic mutations, including the loss of heterozygosity on human chromosome $10 \mathrm{q}$, the homozygous deletion of p16INK4a and mutations in Rb and TP53 genes, cyclin-dependent kinases and the tyrosine kinase signaling pathway. Based on the aforementioned genetic mutations shown in The Cancer Genome Atlas (27), four subtypes of GBM have been defined: Proneural, neural, classical and mesenchymal. The first subtype is characterized by the hyperexpression of transcription factor SOX2, oligodendrocyte transcription factor 2 and platelet-derived growth factor genes. The second subtype is characterized by the expression of glial cell-derived neurotrophic factor, brain-derived neurotrophic factor, insulin-like growth factor 1 and other neuron-related genes. The third subtype is characterized by mutations in the EGFR gene, and mutations in the neurofibromin gene are found in the fourth subtype. For the last 10 years, this classification system has expanded based on the data from genome-wide association studies $(28,29)$, and significant differences in the molecular landscapes of cancer cells in primary and recurrent tumors (30) have been described, indicating a high plasticity of GBM cells.

Cancer cell plasticity is mostly due to epigenetic damage. Notably, in 2016 the World Health Organization (25) selected the isocitrate dehydrogenase (IDH) $1 \backslash 2$ mutations as the main determinant of prognosis for patients with GBM, as these mutations result in an excess of 2-hydroxyglutarate in cancer cells that causes hypermethylation of the genome (31). This includes hypermethylation of the promoter regions of O6-methylguanine-DNA methyltransferase, which is responsible for the repair of damaged DNA and the subsequent adaptation to radiation and chemotherapy. The IDH-mutant GBM often affects patients of a young age, developing from a diffuse or anaplastic astrocytoma and becoming localized in the frontal cortex (32). The IDH-wild-type GBM constitutes up to $90 \%$ of cases, develops de novo, and is localized in parietal, occipital or temporal areas of the brain. The median survival of patients with IDH-mutant GBM is 23 months, and for those with IDH-wild-type GBM is 13 months.

At the cellular level, treatment resistance is associated with CSCs (33) that have a large combination of genetic and epigenetic alterations. These cells were initially discovered in 1997, when Bonnet and Dick (34) described the cell hierarchy of acute myeloid leukemia based on a primitive CSC. These cells have since been described for lung (35), breast (36), ovarian (37) and colon (38) cancer, GBM and other malignant tumors. CSCs are characterized by plasticity (39), are capable of infinite self-renewal and have the highest proliferation rate among all GBM cells. Only $\sim 100$ cells are required for GBM development in mammals (40), highlighting their oncogenic potential. The ability to repair DNA in a fast and effective manner renders CSCs resistant to treatment (41) and chemotherapy (42).

CSCs acquire a number of new oncogenic properties by interacting with neural stem and progenitor cells residing in the subventricular zone (43-45) and other germinal centers of the human brain. Activation of primitive self-organization mechanisms of CSCs $(46,47)$ allows them to actively interact with other stem and differentiated cells (48), enabling the exchange of genes, chromosomes and whole nuclei (49), thereby increasing the viability of the tumor and its resistance to treatment.

The main requirement (50) for CSCs to activate their interaction with the ECM is the increased production of key cytokines for the remodeling phase of inflammation, including TGF- $\beta$. Under normal conditions, TGF- $\beta$ synthesis begins at the periphery of the inflammatory area, and its source is 
M2-activated macrophages and other immunocytes. This cytokine inhibits proliferation and induces apoptosis in pathologically altered cells, thereby triggering remodeling (51). Mutations in either SMAD or death domain-associated protein 6 signaling pathways allows GBM cells to escape apoptosis (52). Moreover, GBM cells self-activate TGF- $\beta$ and increase the levels of its synthesis based on autocrine induction.

TGF- $\beta$ inhibits inflammation, triggers ECM repair, increases the interaction between cancer cells and the ECM (53), creates a niche for cancer cells (54), hinders T cell proliferation, suppresses antigen presentation by macrophages, inhibits the expression of major histocompatibility complex (MHC) class II antigens by dendritic cells (DCs), increases the synthesis rate of atypical human leukocyte antigen molecules and activates M2 microglia (55) (Fig. 1). Subsequently, as a result of inhibiting $\mathrm{T}$ cells via the production of programmed cell death protein (PD)-1 and cytotoxic T lymphocyte-associated protein 4 by the tumor, the exhausted phenotype of $\mathrm{T}$ lymphocytes is created to interact with regulatory $\mathrm{T}$ cells, M2-macrophages and myeloid-derived suppressor cells (56). Thus, CSCs are isolated from the immune system, creating an optimum living environment and increasing the production of kynurenine pathway metabolites in the tumor $(57,58)$; these metabolites act as negative controls of local inflammation. However, the ability of GBM to resist all existing types of treatment is not only due to local factors, but also immunosuppressive mechanisms.

Key factors of systemic immunosuppression in GBM are radiation and chemotherapy (59). Following chemoradiation treatment in vitro in GBM cells, these cells produce increased levels of IL-10, IL-6, prostaglandin E2 and other immunosuppressive factors (60). Moreover, the supernatant obtained during cell culturing directly suppressed the proliferation of $\mathrm{CD}^{+}$and $\mathrm{CD}^{+} \mathrm{T}$ lymphocytes (61). After receiving 30 fractions of radiation, lymphocytes circulating in the blood flow accumulated an average radiation dose of $2.3 \mathrm{~Gy}$, while the average amount of $\mathrm{CD} 4^{+}$cells in the patients' body decreased by two-fold following chemoradiation, and remained low for a year (62). As patients are recommended radiation treatment $\left(75 \mathrm{mg} / \mathrm{m}^{2} /\right.$ day) along with six subsequent cycles of TMZ treatment $\left(150-200 \mathrm{mg} / \mathrm{m}^{2} /\right.$ day), subsequent adjuvant therapy with chemotherapeutic drugs leads to the inhibition of immunopoiesis in the red bone marrow (63-65). The use of corticosteroids $(9,66,67)$ that have an adverse effect on the survival of patients with GBM is another factor of systemic immunosuppression.

Therefore, local immunosuppression and systemic immunodeficiency create optimal conditions for CSCs to fulfill their lethal potential, and a combination of these factors decreases the survival rate of patients.

\section{Immune privilege of the CNS}

Despite notable advances in the IT of malignant neoplasms, the application of IT in brain tumors has only been an option in recent decades (5). For $>50$ years, the brain was considered an immune-privileged organ (68), due to its lack of a lymphatic system and isolation from other tissues by the blood-brain barrier. This notion was based on the research by Medawar (69), who demonstrated the potential allogeneic graft acceptance in a rodent brain, while other grafts were rejected by the immune system. Furthermore, immunocyte functions in the brain have previously been associated with cells of resident microglia that originate from the yolk sac, which maintain their population through proliferation without any interaction with the immune system cells (70).

It is considered that microglia serve a key role (71) in antigen presentation to immunocytes in numerous diseases of the CNS. Tumor growth in the brain is accompanied by recruitment of microglial cells into the neoplastic tissue (72), where they interact with $\mathrm{T}$ lymphocytes and other immune cells that can freely penetrate the damaged blood-brain barrier, or penetrate the tumor via the cerebrospinal and interstitial fluid. The potential of antigen-presenting cells to use the lymphatic vessels to enter the deep lymph nodes of the neck has previously been demonstrated, where they interact with $\mathrm{T}$ and $\mathrm{B}$ cells contributing to the immune response $(73,74)$. Therefore, the brain is an organ with both strong immune supervision and immune response. Preliminary vaccination with graft antigens (75) inhibits the potential of graft acceptance by the brain, which is the dominant principle of IT for the treatment of CNS tumors.

\section{IT and CSC control}

The presence of specific antigens in cancer cells is a key element of successful IT (76). Since 2009, the National Cancer Institute in the USA has regularly updated this list of antigens $(5,6)$, which include IL-13 receptor $\alpha 2$ (IL13R $\alpha 2$ ) and HER2. IL13R $\alpha 2$ is expressed by $60-80 \%$ of GBM cells, is absent in healthy CNS cells, yet is often found in kidney cells. HER 2 is expressed by $>80 \%$ of GBM cells, but is also present in healthy tissues (77). The first phase of a clinical trial that aimed to target these antigens (78) demonstrated that the size of the tumor lesion and the associated risk level may be reduced; however, there was no significant increase in the survival rates of patients. In this case, IT may not be successful, as it is not specifically targeting CSCs, which have almost no specific antigens. Therefore, further investigations into the molecular targets are required to eliminate CSCs.

In order to specifically target CSCs, a number of proteins have been targeted, including heat shock proteins (79-81), telomerase reverse transcriptase (82), Wilms' tumor protein $(83,84)$, glycoprotein 100 (85), tyrosinase-related protein 2 (86), ephrin type-A receptor $2(87,88)$, A2B5 protein $(89,90)$, SOX family of transcription factors (91) and cytomegalovirus phosphoprotein 65 (92), among others. Alternative methods include the delivery of specific antigens to CSCs, using adenoviruses, lentiviruses, parvovirus and recombinant polioviruses DNX-2401 and PVS-RIPO (93-95). However, the relative treatment success associated with these methods remains low. Selective elimination of CSCs in GBM is currently not an option, and therefore requires the development of novel and more systemic approaches.

CSCs are characterized by the heterogeneous nature of molecular genetic landscapes (96) not only in cell clones, but also in singular cells (97), and these have previously been extracted from tumor biopsy samples. Numerous immunocytochemical markers of CSCs (98-100) and metabolic pathway maps of cancer cells have been described, and notable differences have been demonstrated between patients with primary 


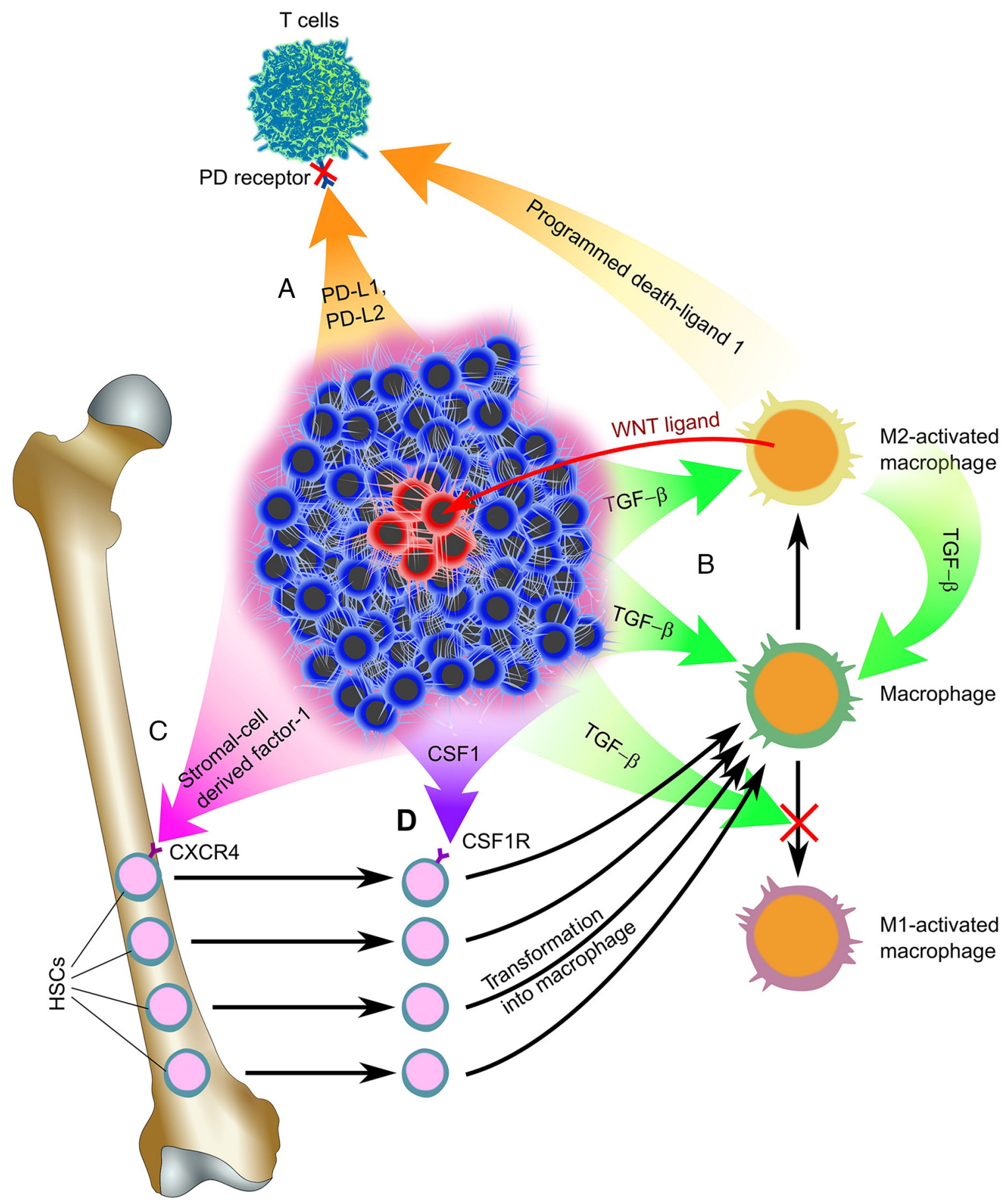

Figure 1. Mechanisms of interaction between glioblastoma multiforme cells and the immune system. (A) Tumor cells produce PD-Ls (PD-L1 and PD-L2) that bind to the PD- 1 receptor on the surface of T cells, which causes T cell anergy and blocks adaptive immunity. (B) The tumor produces a large amount of TGF- $\beta$, which activates macrophages along the alternative (M2) pathway; in response, macrophages intensively produce TGF- $\beta$, which prevents their activation along the classical pathway and turns off active immunity. (C) Tumor cells and damaged tissues produce a large amount of stromal cell-derived factor-1 (also known as C-X-C motif chemokine ligand 12), which is a chemokine of the C-X-C subfamily that interacts with the CXCR4 receptor on the membrane of HSCs and monocytes attracting them into the tumor, thereby enhancing immunosuppression and suppressing inflammation. (D) The production of CSF1 by tumor cells activates CSF1R on the membrane of normal stem cells and monocytes, which transforms them into macrophages activated by TGF- $\beta$ through the alternative pathway. PD, programmed cell death; PD-L, PD ligand; HSCs, hematopoietic stem cells; CSF1, colony stimulating factor 1; CSF1R, CSF1 receptor; CXCR4, C-X-C chemokine receptor type 4 .

and recurrent GBM. In addition, cancer cells that are immunopositive for the main CSC marker, CD133 antigen (101), do not always demonstrate properties of CSCs, while CD133 cancer cells may demonstrate these (102). However, the development of a systemic approach to CSCs should focus on the role of these cells in the pathogenesis of GBM.
Proliferation is a key property of CSCs, and intensive proliferation is accompanied by a notable increase in cancer cell number, leading to an increased oxygen consumption and hypoxia development (103). Long-term hypoxia is detrimental for all cancer cells, including CSCs $(33,40)$. These cells can survive by triggering angiogenesis and providing 
Table I. Completed clinical trials of CAR-T cell therapy in patients with GBM.

\begin{tabular}{|c|c|c|c|c|}
\hline $\begin{array}{l}\text { ClinicalTrials.gov } \\
\text { identifier }\end{array}$ & Phase & Antigen & Type of GBM & $\begin{array}{l}\text { CSC-targeted } \\
\text { therapy }\end{array}$ \\
\hline NCT02664363 & I & EGFRvIII-CAR-T cells & $\begin{array}{l}\text { Newly diagnosed WHO Grade IV } \\
\text { malignant glioma }\end{array}$ & No \\
\hline NCT03283631 & I & EGFRvIII CAR-T cells & Recurrent GBM & No \\
\hline NCT02209376 & I & $\begin{array}{l}\text { Autologous CAR-T cells redirected to } \\
\text { EGFRvIII-receptor }\end{array}$ & EGFRvIII + GBM & No \\
\hline NCT01109095 & I & $\begin{array}{l}\text { CMV-specific cytotoxic T lymphocytes } \\
\text { expressing } \\
\text { CAR targeting HER } 2\end{array}$ & Newly diagnosed and recurrent GBM & No \\
\hline NCT03726515 & I & EGFRvIII CAR-T cells + pembrolizumab & $\begin{array}{l}\text { Newly diagnosed, MGMT-unmethylated } \\
\text { GBM }\end{array}$ & No \\
\hline NCT01454596 & I-II & EGFRvIII CAR-T Cells & EGFRvIII + GBM & No \\
\hline
\end{tabular}

GBM, glioblastoma multiforme; CSC, cancer stem cell; CAR, chimeric antigen receptor, WHO, World Health Organization; v, variant; CMV, cytomegalovirus; MGMT, $\mathrm{O}^{6}$-methylguanine-DNA methyl-transferase.

the corresponding tumor with a blood supply, and this is only possible through interaction with the ECM (48). Previous cell proteome studies have demonstrated that increased synthesis of proteins associated with the ECM-receptor interaction signaling pathway is a key difference between CSCs and differentiated GBM cells (53). Proteome profiles of CSCs and normal stem cells are considered similar (104).

Thus, the optimum targets for managing CSCs may include cell-surface receptors, such as integrin $\mathrm{V}$, integrin $\beta 3$ and integrin $\beta 1$, as well as other components of the ECM-receptor interaction signaling pathway. Optimum targets may also include ECM components secreted by CSCs, such as collagen type VI $\alpha 1$, laminin $\beta 1$, fibronectin 1 and tenascin. Targeting these elements may inhibit the development of the CSC niche, and disrupt the corresponding intercellular interactions mediated by these cells (105). This method may be possible using the technologies of adaptive and active IT.

\section{Adaptive IT}

Adaptive IT involves the extraction of the patient's immune cells in order to activate them to tumor antigens, and subsequently return them to the patient's body. An example of this process involved the vaccination of the patient with the antigens of destroyed cancer cells, along with Bacillus Calmette-Guérin antigens (106). Furthermore, subsequent extraction of $\mathrm{T}$ cells was carried out, and these were additionally stimulated with IL-2 ex vivo, and injected into the patient. In a previous study, vaccination with cancer cell antigens was accompanied by injection of granulocyte-macrophage colony-stimulating factor (GM-CSF), and $\mathrm{T}$ cells were subsequently obtained from the blood, activated ex vivo with Staphylococcus aureus antigens and returned to the patient (107). The use of immunocytes from patients with GBM may not be successful, as these immunocytes have been exhausted by anti-inflammatory cytokines, inhibitors of immune checkpoints and other reprogramming factors produced by GBM cells, as well as by the systemic immune suppressing effect of antitumor treatment. Thus, their cytotoxic effect is relatively low (108).

A further example of adaptive IT involves intravenous or intracranial injection of genetically modified $\mathrm{T}$ cells equipped with chimeric antigen receptors (CAR), where the areas of antigen-recognition domains, consisting of monoclonal antibodies, are connected with the areas of intercellular signaling domains of $\mathrm{T}$ lymphocytes (109). A previous study using rat models and monovalent CAR-T cells targeting IL-13R $\alpha 2$, IDH1-R132H, HER2 or EGFR variant (v) III demonstrated tumor regression, but the clinical application of CAR-T cells (110) is yet to be fully established.

Previous data highlighting 6 clinical trials using CAR-T cells in patients with GBM that have reached phase I are displayed in Table I. The aforementioned trials are limited by the small number of participants, the involvement of patients with recurrent and refractory GBM who have received multiple chemotherapy cycles, limited observation periods and treatment that does not target CSCs (111). Additionally, the combination of CAR-T cell therapy and immune checkpoint inhibitors have been used in patients with first-time diagnoses and recurrent GBM (112). Thus, this method has no clear potential. Moreover, despite a wide range of side effects, the life expectancy of patients with GBM who take part in clinical trials exceeds the life expectancy of those who are treated according to the standard protocol (113). The heterogeneous nature of GBM cells predetermines the need for creating multivalent CAR-T cells that are capable of eliminating cancer cells that express HER2, ephrin type-A receptor 2, IL13R $\alpha 2$ and other antigens (114). Multivalent CAR-T cells that have the ability to inhibit key components of the ECM-receptor interaction signaling pathway in CSCs may act as a potential treatment option for managing CSCs.

\section{Active IT}

Active IT stimulates the development of antitumor immunity following injection of peptide vaccines, including tumor cell vaccines (TCVs) and DC vaccines (DCV). An example of a 
peptide vaccine is rindopepimut, that targets cancer cells expressing a mutant peptide of EGFRvIII (115-117). In March 2016, the phase III ACT IV trial was terminated as the overall survival rate of patients was not increased (118). This may be associated with a lower antigen load due to previous surgery, influence of PD-ligand 1 (PD-L1) or the immunosuppressive effect of radiation and chemotherapy. This peptide vaccine may still be used in complex personalized treatment of patients with GBM cells that express the EGFRvIII antigen.

The development of TCVs involves recruiting immune cells into the blood stream and presenting them with specific antigens, followed by stimulation with pro-inflammatory cytokines that determine the main type of intercellular interactions in the neoplastic lesion. Immunization is performed simultaneously with injecting GM-CSF, and immunocytes are subsequently extracted from the patient's body, activated with Staphylococcus enterotoxin A antigens, multiplied in the culture medium with IL-2 and returned to the patient. Autologous or gene-modified allogeneic cancer cells that are either treated with ultrasound or deactivated with radiation, are used as antigens for TCV creation (6). One TCV has been developed with genetically modified cancer cells producing GM-CSF (119). In addition, a vaccine from radiation-treated autologous cancer cells with inactivated allogeneic cancer cells producing GM-CSF has also been described (55).

Stimulation of GM-CSF (106) is one of the crucial conditions of the effective application of TCVs. In a recent study (120), a GM-CSF injection in animals with implanted glial brain tumor was accompanied by the recruitment of mononuclear $\mathrm{CD} 45^{+}$ cells into the blood flow. The subsequent injection of bacterial lipopolysaccharide and IFN- $\gamma$ enriched the tumor tissue with markers of M1-activated microglial cells, increased the number of antigen-presenting $\mathrm{CD}^{+} 6^{+}$cells, and decreased the amount of TGF- $\beta$ and IL-10 in the tumor, thus destabilizing one of the main mechanisms underlying local resistance to treatment. Notably, such stimulation increased the life expectancy of the experimental animals. Furthermore, stimulation of healthy animals along with the subcutaneous injection of dead cancer cells eliminated the chance of graft acceptance, or notably increased the period of tumor development in rats following the intracranial injection of cancer cells $(55,121)$.

Previous data detailing 78 clinical trials for TCV suggested that only 30 biomedical products passed phase I. These studies were characterized by the small number of patients, lack of a unified approach to selecting patients and complete disregard for local immunosuppression and systemic immunodeficiency. Moreover, only two studies targeted CSCs (NCT00846456 and NCT01171469). Notably, the results of these clinical trials demonstrated that the average life expectancy of patients that received TCV was significantly increased, compared with the control group. However, no biomedical product that is currently on trial can be categorically classified as TCV, as a part of the immunocytes returned to the patient following stimulation with cancer cell antigens includes DCs, which present the antigens with MHC class I and II molecules to T cells. This induces immune aggression in the tumor tissue (122).

DCV is one of the most important elements of adaptive tumor IT. These vaccines are created in a traditional manner, for example, cancer cells are lysed, and incubated with mononuclear $\mathrm{CD} 45^{+}$cells of the red bone marrow and the corresponding cytokine mixture that contains IL1 or IL2, GM-CSF and IFN $\gamma$ (123). DCs attached to the surface of the plate are washed, stimulated with pro-inflammatory cytokines and returned to patients with GBM. DCs migrate from the patient's blood flow into the lymphatic system, and subsequently move into the regional lymph nodes, where they stimulate the proliferation and differentiation of T lymphocytes, enabling an antitumor immune response (124).

DCV-based IT is one of the most promising methods of GBM treatment (125), and in certain cases the median survival of patients is 525 days, compared with a median survival of 380 days for patients who have been treated according to the standard protocol (126). Notably, 52 clinical trials of DCV are currently being conducted, and only 14 have been completed (Table II). Myeloid, lymphoid and plasmacytoid DCs are used to generate DCVs (68). Myeloid DCs are of bone marrow origin from a common hematopoietic CD34(+) stem cell. More mature progenitors of such cells, circulating in the blood, have the morphology of monocytes, but the CD34 antigen is absent on their membrane, while markers of myeloid differentiation CD11c, CD13, CD14 and CD33 are present. Plasmacytoid DCs are of lymphoid origin and are characterized by the absence of myeloid markers; however, they express CD4, CD45RA, BDCA2/CD303, BDCA4/CD304, MHC II antigens and co-stimulatory molecules CD80, CD86 and CD40, and contain a large number of IL3 receptors (70,75). Creation of a DCV (99) is possible using such potential antigens as autologous live cells of GBM, allogeneic cancer cells, lysates of cancer stem CD133(+) and differentiated CD133(-) cells of GBM, as well as a combination of autologous cancer cells, which were previously killed with irradiation, with lysates of allogeneic cancer stem CD133(+) cells. However, a brief analysis of the corresponding results indicated clear differences in the number and composition of the used immunocytes, different vaccination methods, a lack of uniform criteria for evaluating the effectiveness of the vaccine and disregard for issues associated with local immunosuppression and systemic immunodeficiency.

\section{IT and molecular-based therapy}

Solving issues associated with local immunosuppression and systemic immunodeficiency is complex. The increased synthesis of TGF- $\beta$ by GBM cells is a key element of local immunosuppression. Previous studies have focused on suppressing TGF- $\beta$ synthesis with pharmacological agents, such as trabedersen (127) and galunisertib (128), but the use of TGF- $\beta$ inhibitors alone (129) for the management of local immunosuppression was insufficient. Blockade of the signaling axis colony stimulating factor 1 (CSF1)\CSF1 receptor (CSF1R; also known as macrophage colony-stimulating factor receptor) is one of the most important ways of regulating local immunosuppression. CSF1, through CSF1R, induces the differentiation of hematopoietic stem cells (HSCs) and monocytes into tumor-associated macrophages, which under the influence of TGF- $\beta$ are activated along the alternative M2 pathway and markedly increase the synthesis of this cytokine (130). In this regard, certain prospects may be associated with the combination of TGF- $\beta$ inhibitors with CSF1R antagonists (131) such as pexidartinib, emactuzumab and cabiralizumab. 
Table II. Completed clinical trials of dendritic cell vaccines for the treatment of GBM.

\begin{tabular}{|c|c|c|c|c|}
\hline $\begin{array}{l}\text { ClinicalTrials.gov } \\
\text { identifier }\end{array}$ & CSC-targeted IT & Type of GBM & $\begin{array}{c}\text { Phase of } \\
\text { clinical trial }\end{array}$ & $\begin{array}{l}\text { Median survival } \\
\text { time, months }\end{array}$ \\
\hline NCT02049489 & Yes & Recurrent GBM & I & No data \\
\hline NCT00323115 & No & Newly diagnosed GBM & I & 28.0 \\
\hline NCT00576537 & No & All types of GBM & II & No data \\
\hline NCT00846456 & Yes & Newly diagnosed and recurrent GBM & I-II & 23.0 \\
\hline NCT00576641 & No & All gliomas and GBM & I & No data \\
\hline NCT00626483 & No & Newly diagnosed GBM & $\mathrm{I}$ & No data \\
\hline NCT01006044 & No & Newly diagnosed GBM & II & 23.4 \\
\hline NCT03615404 & No & Newly diagnosed and recurrent GBM & $\mathrm{I}$ & No data \\
\hline NCT01213407 & No & Newly diagnosed & I & No data \\
\hline NCT02820584 & No & Recurrent GBM & I & No data \\
\hline NCT00612001 & No & All gliomas & $\mathrm{I}$ & No data \\
\hline NCT01280552 & No & All type of GBM & II & 11.2 \\
\hline NCT00890032 & No & Recurrent GBM & $\mathrm{I}$ & No data \\
\hline NCT00068510 & No & All type of gliomas & 1 & No data \\
\hline
\end{tabular}

GBM, glioblastoma multiforme; CSCs, cancer stem cells; IT, immunotherapy.

Table III. Completed clinical trials of immune checkpoints inhibitors for the treatment of GBM.

\begin{tabular}{|c|c|c|c|}
\hline $\begin{array}{l}\text { ClinicalTrials.gov } \\
\text { identifier }\end{array}$ & Study title & $\begin{array}{l}\text { Phase of } \\
\text { clinical trial }\end{array}$ & Median of survival \\
\hline NCT02798406 & $\begin{array}{l}\text { Multi-center, open-label study of a conditionally replicative adenovirus } \\
\left(\text { DNX-2401) with pembrolizumab }\left(\text { Keytruda }^{\circledR}\right) \text { for recurrent }\right. \\
\text { glioblastoma or liposarcoma }\end{array}$ & II & No results posted \\
\hline NCT03493932 & $\begin{array}{l}\text { Cytokine microdialysis for real-time immune monitoring in } \\
\text { glioblastoma patients undergoing checkpoint blockade }\end{array}$ & I & No results posted \\
\hline NCT02550249 & Neoadjuvant nivolumab in glioblastoma (neo-nivo) & II & No results posted \\
\hline NCT03636477 & $\begin{array}{l}\text { A study of Ad-RTS-hIL-12 with veledimex in combination with } \\
\text { nivolumab in subjects with glioblastoma; a substudy to ATI001-102 }\end{array}$ & I & No results posted \\
\hline NCT02327078 & $\begin{array}{l}\text { A study of the safety, tolerability, and efficacy of epacadostat } \\
\text { administered in combination with nivolumab in select advanced } \\
\text { cancers (ECHO-204) }\end{array}$ & INI & No results posted \\
\hline NCT02335918 & $\begin{array}{l}\text { A dose escalation and cohort expansion study of anti-CD27 } \\
\text { (varlilumab) and anti-PD-1 (nivolumab) in advanced refractory } \\
\text { solid tumors }\end{array}$ & IVI & No results posted \\
\hline NCT02529072 & $\begin{array}{l}\text { Nivolumab with dendritic cells vaccines for recurrent brain tumors } \\
\text { (AVERT) }\end{array}$ & I & $\begin{array}{l}\sim 4 \text { years from study } \\
\text { initiation }\end{array}$ \\
\hline
\end{tabular}

PD-1, programmed cell death protein 1; Ad-RTS-hIL-12, human interleukin-12 vector.

In addition, local immunosuppression is caused by the production of PD-L1 and other molecules from cancer cells (132-134), which inhibit receptor activation on cytotoxic T lymphocytes (135) allowing cancer cells to take control of the immune system. Notably, following PD-L1 stimulation, resident tumor microglia with $\mathrm{M} 2$ activation not only increase the levels of these ligands, but also induce monocyte-derived macrophages that inhibit the immune response and promote tumor growth (136). Nivolumab, an inhibitor of PD-1 receptors, is able to direct the tumor microglia to the M1-phenotype and alter the microsurroundings of cancer cells (137). However, the combination of TGF- $\beta$ antagonists with agents that prevent neutralization of $\mathrm{T}$ lymphocytes remains inefficient (138). Only seven clinical trials of immune checkpoint inhibitors in the complex treatment of glioblastoma have been completed worldwide to date (Table III).

Bevacizumab is a monoclonal antibody that targets vascular endothelial growth factor (139-141), and when used 
together with TMZ, has been indicated to increase the average life expectancy of patients with GBM from 6.5 to 9.5 months. Nivolumab is more effective than bevacizumab (142), but a combination of these agents allows the treatment of cerebral edema without corticosteroids $(6,143)$, which enhances the potential of IT. However, a significant increase in the life expectancy of patients is yet to be achieved, which highlights issues associated with these treatment methods that are more profound. Nevertheless, despite the small number of completed clinical trials (Table III), immune checkpoint inhibitors are among the most promising drugs for immunochemotherapy of GBM.

\section{HSCs and IT}

The results of previous studies have demonstrated that patients with GBM with a high level of leukocytes exhibit an improved prognosis following the use of antitumor vaccines (144), inhibitors of immune checkpoint (145-147) and other immunotherapeutic agents. This indicates the impact of systemic immunodeficiency caused by the damage to the bone marrow tissues following radiation and chemotherapy. Systemic solutions involve transplantation of HSCs. In cases of unimpaired hematopoiesis, the proportion of HSCs in the blood of a healthy individual does not exceed $0.01 \%$, and stimulation with GM-CSF increases the number of HSCs in the blood $>100$-fold, which allows HSC extraction for further use in the reconstruction of the immune system (148). However, this task is difficult to achieve. Following radiation and several courses of chemotherapy, the bone marrow of patients becomes exhausted $(132,133)$, and it is impossible to obtain an adequate quantity of HSCs for transplantation. This issue may be resolved with the transplantation of autologous HSCs obtained from the patient, that have been cryopreserved prior to disease occurrence, but only a number of patients have this option.

Restoring the immune system of a patient using autologous HSCs may not be the only option, as the development of novel antitumor immunity may counter high levels of tumor aggression. In the entire existence of both mammals and humans, infective agents have posed serious threats; however, life expectancies were never long enough for cancer development. Thus, evolution has led to the development of a number of mechanisms for eliminating pathologically altered cells (such as inflammation, apoptosis and autophagy), but only if their number is relatively small and it does not interfere with cell or tissue homeostasis (149).

HSCs are progenitors of the immune system, as well as coordinators and stabilizers of regeneration processes. Proliferation speed and the number of these cells decreases with age, thus reducing the levels of immune protection and increasing the number of pathologically altered cells in the body. Notable increases in the number of cancer cells are observed during the rapid invasive growth of GBM, resulting in the destruction of neurons and glial cells, inflammation, cerebral ischemia and the intensified production of chemo-attractants that stimulate the migration of HSCs into the brain (150).

The key mechanism underlying the recruitment of HSCs into the tumor lesion is carried out by hypoxia-inducible factors a group of ligands that activate the production of $>80$ cytokines by damaged tissues. Key cytokines involved

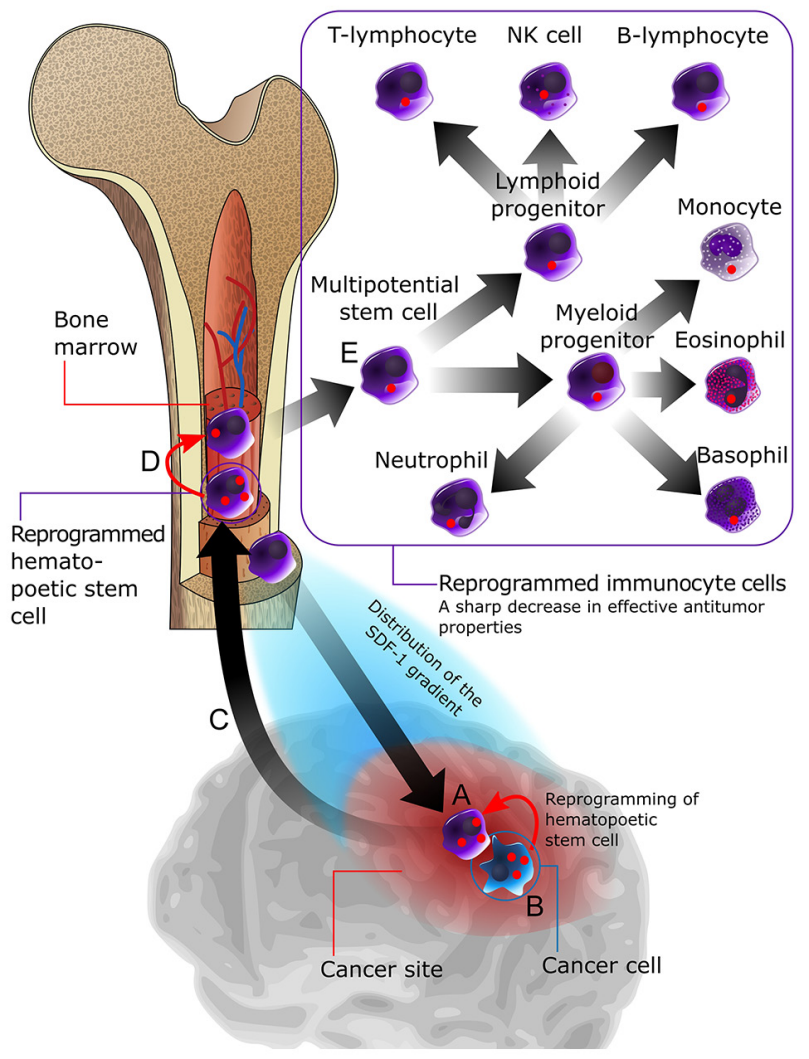

Figure 2. Reprogramming of healthy HSCs when interacting with CSCs of GBM allows the tumor to avoid being targeted by the immune system. (A) HSCs with C-X-C chemokine receptor type 4 on their cell membrane migrate from the bone marrow into the tumor, along with a concentration gradient of SDF-1. (B) Reprogramming of HSCs when interacting with CSCs. (C) Migration of reprogrammed HSCs back to the bone marrow and reprogramming of further HSCs. (D) Appearance of reprogrammed progenitor cells and (E) reprogrammed immunocytes that are non-reactive towards CSCs and cancer cells of GBM. HSCs, hematopoietic stem cells; CSCs, cancer stem cells; GBM, glioblastoma multiforme; SDF-1, stromal cell-derived factor-1.

in this process include monocyte chemoattractant protein-1 and stromal cell-derived factor- $1 \alpha$, which interact with $\mathrm{C}-\mathrm{C}$ motif chemokine 2 and $\mathrm{C}-\mathrm{X}-\mathrm{C}$ chemokine receptor type 4 receptors on the HSC membrane, and induce their migration to the tumor lesion (151). Results of a previous study demonstrated that following 3 days of HSC injections into rats with implanted C6 gliomas, the transplanted cells migrated into the tumor and were visible in the blood vessels of glioma (152). In addition, following 4 and 5 days of the experiment, these cells penetrated areas of invasive growth and necrotic segments of neoplastic tissue, where they aggregated and interacted with cancer cells.

Briefly, HSCs adhere to cancer cells and interact with them, which has been demonstrated by the aggregation of fluorescent stain in cancer cells that is bound to the HSC cytoplasmic proteins during this interaction (153). Results of a previous in vitro study revealed that aggregation of the stain in the cancer cells decreased the adhesion to the culture plate surface and eliminated the interaction with the ECM, due to TGF- $\beta$ stimulation and reduced proliferation of GBM cells (154). This effect became more pronounced when the cancer cell: HSC cell ratio reached 1:3, indicating the antitumor potential of HSCs. In natural conditions, aggregation of normal stem cells in a damaged 


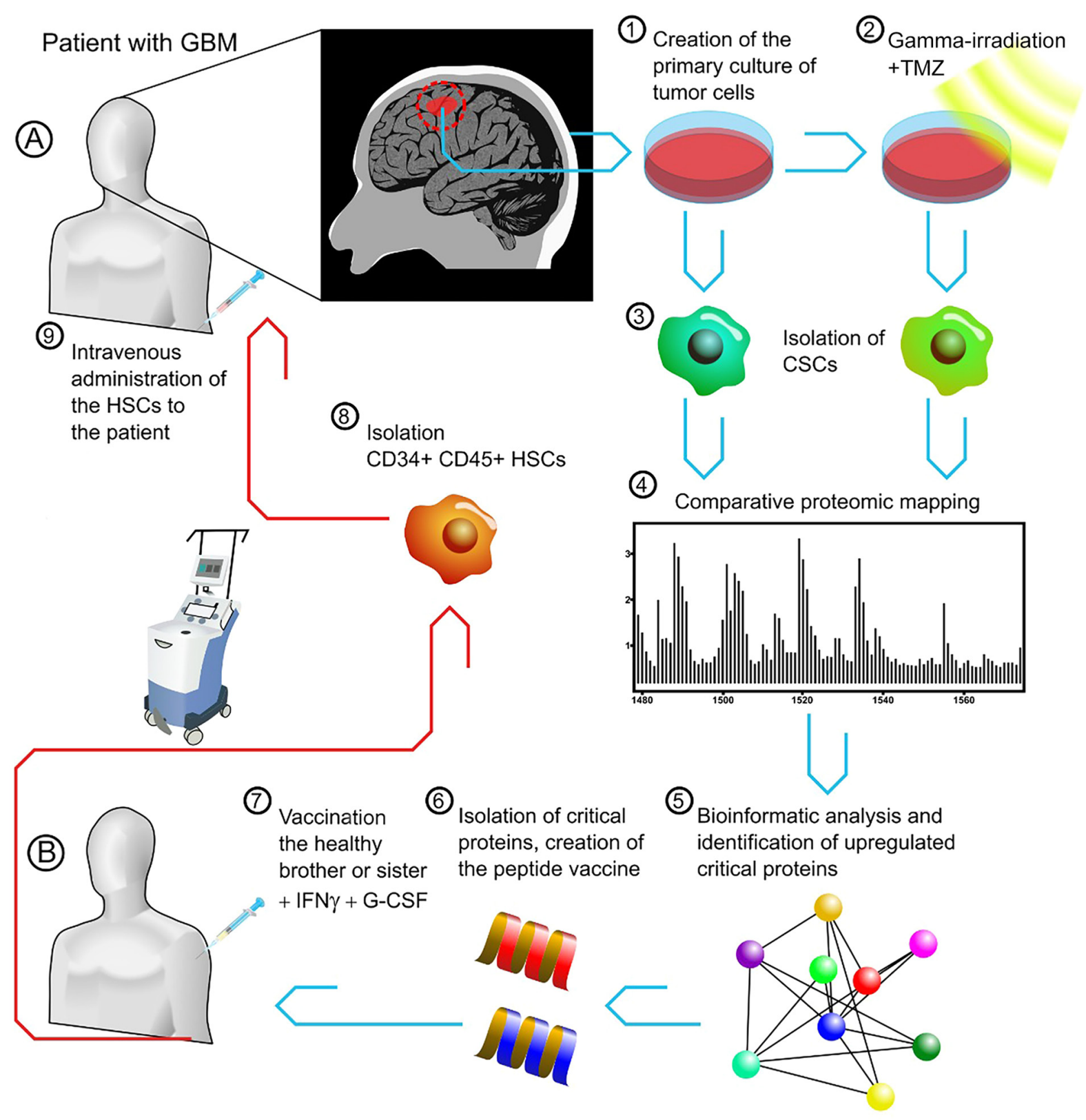

Figure 3. Hypothetical scheme for immunotherapy of GBM using donor HSCs. (A) Patient with newly diagnosed GBM who has been treated according to the standard protocol. (B) Healthy donor is a sibling of a patient with GBM. Step 1: Obtaining a primary culture of GBM cells from cancer tissue which was removed from the patient's brain during surgery. Step 2: $\gamma$-irradiation of the culture of primary GBM cells in vitro at a dose of $60 \mathrm{~Gy}$, with the addition of TMZ to the medium. Step 3: Cultivation of cells of primary and irradiated GBM on serum-free media with subsequent isolation of CSCs from glioma spheres. Step 4: Comparative proteome mapping of primary and irradiated CSCs. Step 5: Bioinformatic analysis of cellular proteomes with the identification of proteins that are maximally upregulated in irradiated CSCs. Step 6: Isolation of proteins upregulated in irradiated CSCs and creation of a peptide vaccine. Step 7: Vaccination of individual B with a peptide vaccine based on upregulated proteins of irradiated CSCs, in combination with an injection of G-CSF and IFN- $\gamma$. Step 8: Isolation of CD34(+) CD45(+) cells from the bloodstream of individual B. Step 9: Subsequent transplantation into the bloodstream of patient A. GBM, glioblastoma multiforme; CSCs, cancer stem cells; G-CSF; granulocyte colony-stimulating factor; HSCs, hematopoietic stem cells; TMZ, temozolomide.

area results in M2-polarization of macrophages, suppression of antigen presentation, increased production of IL-4 and other anti-inflammatory cytokines, accompanied by the apoptosis of pathologically altered cells, clearance of the dead cells and debris of the phlogogenic site, and ECM remodeling (155). Thus, disruption of the interaction between CSCs and the ECM induced by HSCs is a powerful regulatory stimulus.

Furthermore, the exchange of the fluorescent stain is not one-sided, indicating the transfer of information in both directions. When HSCs interact with cancer cells, their cytoplasm also displays fluorescent stain aggregation and the transfer of specific proteins, accompanied by the epigenetic reprogramming of HSCs (154). The ability of these cells to effectively restore hematopoiesis and immunopoiesis requires further investigation; however, a previous clinical trial demonstrated that oncologic and autoimmune diseases cause significant changes in the molecular phenotype of HSCs, impacting treatment outcomes and the prognosis of patients (156).

Thus, whether GBM develops only as a result of pathological transformation of neural stem cells in the human brain, or arises as a result of the interaction of normal neural stem cells with HSCs remain to be fully elucidated. During an in vitro 
experiment, neural stem cells demonstrated a high mobility to cancer cells of different lines, and this level of migration was markedly increased between neural stem cells and GBM cells, which may be attributed to their origin from the same histogenetic source in the central nervous system Additionally, GBM cells demonstrated a high mobility towards neural stem cells, actively interacting with them and exchanging fluorescent stain. HSCs are stem cells of a different origin, but their mobility towards GBM cells is not as active as that of neural stem cells (152) Notably, unlike stem cells in germinal regions of the brain, HSCs play a key part in the mechanisms underlying the memory retention of antigens, managing the processes of immune tolerance and immunocyte activation (157). Following the aforementioned antitumor vaccination, HSCs may inactivate the immune system, leading to ineffective methods for the treatment of GBM (Fig. 2).

Collectively, the aforementioned research demonstrated that transplantation of autologous HSCs to patients with GBM is not a systemic approach to the issue of immunodeficiency. Based on the hypothesis that epigenetic reprogramming of HSCs occurs during their interaction with cancer cells, IT may only be effective following complete regeneration or replacement of the immune system, using allogeneic HSCs of a healthy donor. The allogeneic transplantation of bone marrow should become the basis for a novel approach to GBM treatment. Both the duration and quality of remission for patients with leucosis (158) and multiple myeloma (159), who have received allotransplantation of bone marrow, are significantly improved. This is directly associated with the initiated graft-versus-tumor effect. This approach requires extensive further investigation; however, future treatment options should involve the use of allogeneic HSCs.

\section{Conclusion}

Modern oncology exhibits a wide range of antitumor products and methods. However, despite all recent scientific advances, the survival rates of patients with GBM still remains low. This issue requires novel systemic solutions, but novel treatment options for patients with GBM should not be confined to medication, radiation or a combination of both methods. GBM treatment success is dependent on the use of modern surgical, radiation and chemotherapy methods. Cytoreductive, cytotoxic and cytostatic therapies are a first treatment stage that must involve CSC management in order to be successful. At present, the only method of managing CSCs is IT, but fulfilling the cytoregulatory potential of IT is only possible following complete restoration of the immune system functions.

HSC transplantation should be performed directly after chemoradiation treatment. Autologous HSCs obtained from the patient prior to disease development should be the first choice for a graft. Therefore, cryopreservation of HSCs is required, to allow potential cancer treatment before its occurrence. If this option is unavailable, transplantation of allogeneic HSCs from a biologically compatible donor may be considered; however, further experimental studies are required.

Subsequent IT should be based on the use of immunocytes from a healthy donor that are targeted against the key proteins of CSCs, with a main focus on components of the ECM-receptor interaction signaling pathway. Following HSC transplantation and restoration of healthy immunopoiesis, TCVs are required, based on CSC antigens, DCVs and multivalent CAR-T cells targeting key elements of the ECM-receptor interaction signaling pathway. Such IT should be used in combination with inhibitors of the immune checkpoint, antagonists of TGF- $\beta$ and antiangiogenic agents.

The assumption that HSCs are the main tool of the immune memory requires a healthy donor to receive a vaccine based on key CSC antigens prior to obtaining HSCs. This would allow the production of biomedical HSC-based products for personalized proteome-based GBM therapy (Fig. 3). This method requires further experimental and clinical investigation; however, the current review may provide a theoretical basis for the development of novel GBM treatment options.

\section{Acknowledgements}

Not applicable.

Funding

No funding was received.

\section{Availability of data and materials}

Not applicable.

\section{Author's contributions}

IB designed and wrote the review, and approved the final version of the manuscript. Data authentication is not applicable.

\section{Ethics approval and consent to participate}

Not applicable.

\section{Patient consent for publication}

Not applicable.

\section{Competing interests}

The authors declare that they have no competing interests.

\section{References}

1. Lukas RV, Wainwright DA, Ladomersky E, Sachdev S, Sonabend AM and Stupp R: Newly diagnosed glioblastoma: A review on clinical management. Oncology (Williston Park) 33: 91-100, 2019.

2. Stupp R, Mason WP, van den Bent MJ, Weller M, Fisher B, Taphoorn MJ, Belanger $\mathrm{K}$, Brandes AA, Marosi C, Bogdahn U, et al: Radiotherapy plus concomitant and adjuvant temozolomide for glioblastoma. N Engl J Med 352: 987-996, 2005.

3. Gimple RC, Bhargava S, Dixit D and Rich JN: Glioblastoma stem cells: Lessons from the tumor hierarchy in a lethal cancer. Genes Dev 33: 591-609, 2019.

4. Lathia JD, Mack SC, Mulkearns-Hubert EE, Valentim CL and Rich JN: Cancer stem cells in glioblastoma. Genes Dev 29: 1203-1217, 2015.

5. Jackson CM, Choi J and Lim M: Mechanisms of immunotherapy resistance: Lessons from glioblastoma. Nat Immunol 20: $1100-1109,2019$. 
6. McGranahan T, Therkelsen KE, Ahmad S and Nagpal S: Current state of immunotherapy for treatment of glioblastoma. Curr Treat Options Oncol 20: 24, 2019.

7. Chongsathidkiet P, Jackson C, Koyama S, Loebel F, Cui X, Farber SH, Woroniecka K, Elsamadicy AA, Dechant CA, Kemeny HR, et al: Sequestration of T cells in bone marrow in the setting of glioblastoma and other intracranial tumors. Nat Med 24: 1459-1468, 2018

8. Waziri A: Glioblastoma-derived mechanisms of systemic immunosuppression. Neurosurg Clin N Am 21: 31-42, 2010

9. Pitter KL, Tamagno I, Alikhanyan K, Hosni-Ahmed A, Pattwell SS, Donnola S, Dai C, Ozawa T, Chang M, Chan TA, et al: Corticosteroids compromise survival in glioblastoma. Brain 139(Pt 5): 1458-1471, 2016.

10. Omuro A and DeAngelis LM: Glioblastoma and other malignant gliomas: A clinical review. JAMA 310: 1842-1850, 2013.

11. Tan AC, Ashley DM, López GY, Malinzak M, Friedman HS and Khasraw M: Management of glioblastoma: State of the art and future directions. CA Cancer J Clin 70: 299-312, 2020.

12. Weller M, Le Rhun E, Preusser M, Tonn JC and Roth P: How we treat glioblastoma. ESMO Open 4(Suppl 2): e000520, 2019.

13. Nam JY and de Groot JF: Treatment of glioblastoma. J Oncol Pract 13: 629-638, 2017.

14. Scartoni D, Amelio D, Palumbo P, Giacomelli I and Amichetti M Proton therapy re-irradiation preserves health-related quality of life in large recurrent glioblastoma. J Cancer Res Clin Oncol 146 $1615-1622,2020$

15. Miyatake SI, Wanibuchi M, Hu N and Ono K: Boron neutron capture therapy for malignant brain tumors. J Neurooncol 149: $1-11,2020$.

16. Lesueur P, Lequesne J, Grellard JM, Dugué A, Coquan E, Brachet PE, Geffrelot J, Kao W, Emery E, Berro DH, et al: Phase I/IIa study of concomitant radiotherapy with olaparib and temozolomide in unresectable or partially resectable glioblastoma: OLA-TMZ-RTE-01 trial protocol. BMC Cancer 19: 198, 2019.

17. Bostian AC, Maddukuri L, Reed MR, Savenka T, Hartman JH, Davis L, Pouncey DL, Miller GP and Eoff RL: Kynurenine signaling increases DNA polymerase kappa expression and promotes genomic instability in glioblastoma cells. Chem Res Toxicol 29: 101-108, 2016.

18. Khotimchenko R, Bryukhovetskiy I, Khotimchenko M and Khotimchenko Y: Bioactive compounds with antiglioma activity from marine species. Biomedicines 9: 886, 2021.

19. Anthony P, McArdle S and McHugh M: Tumor treating fields: Adjuvant treatment for high-grade gliomas. Semin Oncol Nurs 34: 454-464, 2018.

20. Di Nunno V, Franceschi E, Tosoni A, Di Battista M, Gatto L, Lamperini C, Minichillo S, Mura A, Bartolini S and Brandes AA: Treatment of recurrent glioblastoma: State-of-the-art and future perspectives. Expert Rev Anticancer Ther 20: 785-795, 2020.

21. Kazmi F, Soon YY, Leong YH, Koh WY and Vellayappan B: Re-irradiation for recurrent glioblastoma (GBM): A systematic review and meta-analysis. J Neurooncol 142: 79-90, 2019.

22. Gigliotti MJ, Hasan S, Karlovits SM, Ranjan T and Wegner RE Re-Irradiation with stereotactic radiosurgery/radiotherapy for recurrent high-grade gliomas: Improved survival in the modern Era. Stereotact Funct Neurosurg 96: 289-295, 2018.

23. Weller M and Le Rhun E: How did lomustine become standard of care in recurrent glioblastoma? Cancer Treat Rev 87: 102029, 2020.

24. Schmidt F, Fischer J, Herrlinger U, Dietz K, Dichgans J and Weller M: PCV chemotherapy for recurrent glioblastoma. Neurology 66: 587-589, 2006.

25. Louis DN, Perry A, Reifenberger G, von Deimling A, Figarella-Branger D, Cavenee WK, Ohgaki H, Wiestler OD, Kleihues P and Ellison DW: The 2016 World Health organization classification of tumors of the central nervous system: A summary. Acta Neuropathol 131: 803-820, 2016.

26. Soomro SH, Ting LR, Qing YY and Ren M: Molecular biology of glioblastoma: Classification and mutational locations. J Pak Med Assoc 67: 1410-1414, 2017.

27. Verhaak RG, Hoadley KA, Purdom E, Wang V, Qi Y, Wilkerson MD, Miller CR, Ding L, Golub T, Mesirov JP, et al: Integrated genomic analysis identifies clinically relevant subtypes of glioblastoma characterized by abnormalities in PDGFRA, IDH1, EGFR, and NF1. Cancer Cell 17: 98-110, 2010.

28. Jakovlevs A, Vanags A, Gardovskis J and Strumfa I: Molecular classification of diffuse gliomas. Pol J Pathol 70: 246-258, 2019.

29. Bhawe KM and Aghi MK: Microarray analysis in glioblastomas. Methods Mol Biol 1375: 195-206, 2016.
30. Qazi MA, Vora P, Venugopal C, Sidhu SS, Moffat J, Swanton C and Singh SK: Intratumoral heterogeneity: Pathways to treatment resistance and relapse in human glioblastoma. Ann Oncol 28: 1448-1456, 2017

31. Waitkus MS, Diplas BH and Yan H: Biological role and therapeutic potential of IDH mutations in cancer. Cancer Cell 34: 186-195, 2018.

32. Diplas BH, He X, Brosnan-Cashman JA, Liu H, Chen LH, Wang Z, Moure CJ, Killela PJ, Loriaux DB, Lipp ES, et al: The genomic landscape of TERT promoter wildtype-IDH wildtype glioblastoma. Nat Commun 9: 2087, 2018.

33. Najafi M, Mortezaee K and Majidpoor J: Cancer stem cell (CSC) resistance drivers. Life Sci 234: 116781, 2019.

34. Bonnet D and Dick JE: Human acute myeloid leukemia is organized as a hierarchy that originates from a primitive hematopoietic cell. Nat Med 3: 730-737, 1997.

35. Heng WS, Gosens R and Kruyt FAE: Lung cancer stem cells: Origin, features, maintenance mechanisms and therapeutic targeting. Biochem Pharmacol 160: 121-133, 2019.

36. Butti R, Gunasekaran VP, Kumar TVS, Banerjee $P$ and Kundu GC: Breast cancer stem cells: Biology and therapeutic implications. Int J Biochem Cell Biol 107: 38-52, 2019.

37. Ottevanger PB: Ovarian cancer stem cells more questions than answers. Semin Cancer Biol 44: 67-71, 2017.

38. Munro MJ, Wickremesekera SK, Peng L, Tan ST and Itinteang T: Cancer stem cells in colorectal cancer: A review. J Clin Pathol 71: 110-116, 2018.

39. Sharifzad F, Ghavami S, Verdi J, Mardpour S, Mollapour Sisakht M, Azizi Z, Taghikhani A, Łos MJ, Fakharian E, Ebrahimi M and Hamidieh AA: Glioblastoma cancer stem cell biology: Potential theranostic targets. Drug Resist Updat 42: 35-45, 2019.

40. Singh SK, Clarke ID, Terasaki M, Bonn VE, Hawkins C, Squire J and Dirks PB: Identification of a cancer stem cell in human brain tumors. Cancer Res 63: 5821-5828, 2003.

41. Bao S, Wu Q, McLendon RE, Hao Y, Shi Q, Hjelmeland AB, Dewhirst MW, Bigner DD and Rich JN: Glioma stem cells promote radioresistance by preferential activation of the DNA damage response. Nature 444: 756-760, 2006.

42. Beier D, Schulz JB and Beier CP: Chemoresistance of glioblastoma cancer stem cells-much more complex than expected. Mol Cancer 10: 128, 2011.

43. Altmann C, Keller S and Schmidt MHH: The Role of SVZ stem cells in glioblastoma. Cancers (Basel) 11: 448, 2019.

44. Álvarez-Satta M, Moreno-Cugnon L and Matheu A: Primary cilium and brain aging: Role in neural stem cells, neurodegenerative diseases and glioblastoma. Ageing Res Rev 52: 53-63, 2019.

45. Álvarez-Satta M and Matheu A: Primary cilium and glioblastoma. Ther Adv Med Oncol 10: 1758835918801169, 2018

46. Qu K and Ortoleva P: Understanding stem cell differentiation through self-organization theory. J Theor Biol 250: 606-620, 2008.

47. Beccari L, Moris N, Girgin M, Turner DA, Baillie-Johnson P, Cossy AC, Lutolf MP, Duboule D and Arias AM: Multi-axial self-organization properties of mouse embryonic stem cells into gastruloids. Nature 562: 272-276, 2018.

48. Persano L, Rampazzo E, Basso G and Viola G: Glioblastoma cancer stem cells: Role of the microenvironment and therapeutic targeting. Biochem Pharmacol 85: 612-622, 2013.

49. Osswald M, Jung E, Sahm F, Solecki G, Venkataramani V, Blaes J, Weil S, Horstmann H, Wiestler B, Syed M, et al: Brain tumour cells interconnect to a functional and resistant network. Nature 528: 93-98, 2015

50. Taniguchi S, Elhance A, Van Duzer A, Kumar S, Leitenberger JJ and Oshimori N: Tumor-initiating cells establish an IL-33-TGF-beta niche signaling loop to promote cancer progression. Science 369: eaay1813, 2020.

51. Massagué J: TGFbeta in Cancer. Cell 134: 215-230, 2008.

52. Derynck R, Turley SJ and Akhurst RJ: TGF $\beta$ biology in cancer progression and immunotherapy. Nat Rev Clin Oncol 18: 9-34, 2021.

53. Shevchenko V, Arnotskaya N, Pak O, Sharma A, Sharma HS, Khotimchenko Y, Bryukhovetskiy A and Bryukhovetskiy I: Molecular determinants of the interaction between glioblastoma $\mathrm{CD}_{133^{+}}$cancer stem cells and the extracellular matrix. Int Rev Neurobiol 151: 155-169, 2020.

54. Bryukhovetskiy I and Shevchenko V: Molecular mechanisms of the effect of TGF- $\beta 1$ on U87 human glioblastoma cells. Oncol Lett 12: 1581-1590, 2016. 
55. Fecci PE and Sampson JH: The current state of immunotherapy for gliomas: An eye toward the future. J Neurosurg 131: 657-666, 2019.

56. Choi BD, Maus MV, June CH and Sampson JH: Immunotherapy for glioblastoma: Adoptive T-cell Strategies. Clin Cancer Res 25: 2042-2048, 2019.

57. Takenaka MC, Gabriely G, Rothhammer V, Mascanfroni ID, Wheeler MA, Chao CC, Gutiérrez-Vázquez C, Kenison J, Tjon EC, Barroso A, et al: Control of tumor-associated macrophages and T cells in glioblastoma via AHR and CD39. Nat Neurosci 22: 729-740, 2019.

58. Dehhaghi M, Kazemi Shariat Panahi H, Heng B and Guillemin GJ: The gut microbiota, kynurenine pathway, and immune system interaction in the development of brain cancer. Front Cell Dev Biol 8: 562812, 2020.

59. Authier A, Farrand KJ, Broadley KW, Ancelet LR, Hunn MK, Stone S, McConnell MJ and Hermans IF: Enhanced immunosuppression by therapy-exposed glioblastoma multiforme tumor cells. Int J Cancer 136: 2566-2578, 2015.

60. Yovino S, Kleinberg L, Grossman SA, Narayanan M and Ford E: The etiology of treatment-related lymphopenia in patients with malignant gliomas: Modeling radiation dose to circulating lymphocytes explains clinical observations and suggests methods of modifying the impact of radiation on immune cells. Cancer Invest 31: 140-144, 2013.

61. Grossman SA, Ye X, Lesser G, Sloan A, Carraway H, Desideri S and Piantadosi S; NABTT CNS Consortium: Immunosuppression in patients with high-grade gliomas treated with radiation and temozolomide. Clin Cancer Res 17: 5473-5480, 2011.

62. Kim WJ, Dho YS, Ock CY, Kim JW, Choi SH, Lee ST, Kim IH, Kim TM and Park CK: Clinical observation of lymphopenia in patients with newly diagnosed glioblastoma. J Neurooncol 143: 321-328, 2019

63. Sampson JH, Aldape KD, Archer GE, Coan A, Desjardins A, Friedman AH, Friedman HS, Gilbert MR, Herndon JE, McLendon RE, et al: Greater chemotherapy-induced lymphopenia enhances tumor-specific immune responses that eliminate EGFRvIII-expressing tumor cells in patients with glioblastoma. Neuro Oncol 13: 324-333, 2011.

64. Byun HK, Kim N, Yoon HI, Kang SG, Kim SH, Cho J, Baek JG Chang JH and Suh CO: Clinical predictors of radiation-induced lymphopenia in patients receiving chemoradiation for glioblastoma: Clinical usefulness of intensity-modulated radiotherapy in the immuno-oncology era. Radiat Oncol 14: 51, 2019.

65. Gwin WR III, Disis ML and Ruiz-Garcia E: Immuno-oncology in the era of personalized medicine. Adv Exp Med Biol 1168 $117-129,2019$.

66. Alkhalili K, Zenonos G and Fernandez-Miranda JC: Do corticosteroids compromise survival in glioblastoma? Neurosurgery 79 N15-N16, 2016.

67. Klement RJ and Champ CE: Corticosteroids compromise survival in glioblastoma in part through their elevation of blood glucose levels. Brain 140: e16, 2017.

68. Sampson JH, Gunn MD, Fecci PE and Ashley DM: Brain immunology and immunotherapy in brain tumours. Nat Rev Cancer 20: 12-25, 2020.

69. Medawar PB: Immunity to homologous grafted skin; The fate of skin homografts transplanted to the brain, to subcutaneous tissue, and to the anterior chamber of the eye. Br J Exp Pathol 29: 58-69, 1948.

70. Zhou Q, Wang Y and Ma W: The progress of immunotherapy for glioblastoma. Hum Vaccin Immunother 11: 2654-2658, 2015

71. da Fonseca AC, Amaral R, Garcia C, Geraldo LH, Matias D and Lima FR: Microglia in Cancer: For good or for bad? Adv Exp Med Biol 949: 245-261, 2016.

72. Bryukhovetskiy I, Manzhulo I, Mischenko P, Milkina E, Dyuizen I, Bryukhovetskiy A and Khotimchenko Y: Cancer stem cells and microglia in the processes of glioblastoma multiforme invasive growth. Oncol Lett 12: 1721-1728, 2016.

73. Herz J, Louveau A, Da Mesquita S and Kipnis J: Morphological and functional analysis of CNS-associated lymphatics. Methods Mol Biol 1846: 141-151, 2018.

74. Louveau A and Nau JY: Nervous and lymphatic system communicate with each other. 'Zyka virus' unravels its mystery. Rev Med Suisse 11: 1462-1463, 2015 (In French).

75. Lim M, Xia Y, Bettegowda C and Weller M: Current state of immunotherapy for glioblastoma. Nat Rev Clin Oncol 15: 422-442, 2018.

76. Sarah C: Immunotherapy: CAR T cells in glioblastoma. Nat Rev Drug Discov 16: 602, 2017.
77. Li L, Zhu X, Qian Y, Yuan X, Ding Y, Hu D, He X and Wu Y: Chimeric antigen receptor T-cell therapy in glioblastoma: Current and future. Front Immunol 11: 594271, 2020.

78. Ahmed N, Brawley V, Hegde M, Bielamowicz K, Kalra M, Landi D, Robertson C, Gray TL, Diouf O, Wakefield A, et al: HER2-specific chimeric antigen receptor-modified virus-specific $\mathrm{T}$ cells for progressive glioblastoma: A phase 1 dose-escalation trial. JAMA Oncol 3: 1094-1101, 2017.

79. Lettini G, Lepore S, Crispo F, Sisinni L, Esposito F and Landriscina M: Heat shock proteins in cancer stem cell maintenance: A potential therapeutic target? Histol Histopathol 35: 25-37, 2020.

80. Iglesia RP, Fernandes CFL, Coelho BP, Prado MB, Melo Escobar MI, Almeida GHDR and Lopes MH: Heat Shock Proteins in Glioblastoma Biology: Where Do We Stand? Int J Mol Sci 20: 5794, 2019.

81. Ammendola M, Currò G, Memeo R, Curto LS, Luposella M, Zuccalà V, Pessaux P, Navarra G, Gadaleta CD and Ranieri G: Targeting stem cells with hyperthermia: Translational relevance in cancer patients. Oncol 98: 755-762, 2020.

82. Zanetti M: A second chance for telomerase reverse transcriptase in anticancer immunotherapy. Nat Rev Clin Oncol 14: 115-128, 2017.

83. Oji Y, Hashimoto N, Tsuboi A, Murakami Y, Iwai M, Kagawa N, Chiba Y, Izumoto S, Elisseeva O, Ichinohasama R, et al: Association of WT1 IgG antibody against WT1 peptide with prolonged survival in glioblastoma multiforme patients vaccinated with WT1 peptide. Int J Cancer 139: 1391-1401, 2016.

84. Kijima N, Hosen N, Kagawa N, Hashimoto N, Kinoshita M, Oji Y, Sugiyama H and Yoshimine T: Wilms' tumor 1 is involved in tumorigenicity of glioblastoma by regulating cell proliferation and apoptosis. Anticancer Res 34: 61-67, 2014

85. Saikali S, Avril T, Collet B, Hamlat A, Bansard JY, Drenou B, Guegan Y and Quillien V: Expression of nine tumour antigens in a series of human glioblastoma multiforme: Interest of EGFRvIII, IL-13Ralpha2, gp100 and TRP-2 for immunotherapy J Neurooncol 81: 139-148, 2007.

86. Liu G, Khong HT, Wheeler CJ, Yu JS, Black KL and Ying H: Molecular and functional analysis of tyrosinase-related protein (TRP)-2 as a cytotoxic T lymphocyte target in patients with malignant glioma. J Immunother 26: 301-312, 2003.

87. Affinito A, Quintavalle C, Esposito CL, Roscigno G, Giordano C, Nuzzo S, Ricci-Vitiani L, Scognamiglio I, Minic Z, Pallini R, et al: Targeting ephrin receptor tyrosine kinase A2 with a selective aptamer for glioblastoma stem cells. Mol Ther Nucleic Acids 20: 176-185, 2020

88. Qazi MA, Vora P, Venugopal C, Adams J, Singh M, Hu A, Gorelik M, Subapanditha MK, Savage N, Yang J, et al: Cotargeting ephrin receptor tyrosine kinases A2 and A3 in cancer stem cells reduces growth of recurrent glioblastoma. Cancer Res 78: 5023-5037, 2018.

89. Tchoghandjian A, Baeza N, Colin C, Cayre M, Metellus P, Beclin C, Ouafik L and Figarella-Branger D: A2B5 cells from human glioblastoma have cancer stem cell properties. Brain Pathol 20: 211-221, 2010.

90. Baeza-Kallee N, Bergès R, Soubéran A, Colin C, Denicolaï E, Appay R, Tchoghandjian A and Figarella-Branger D: Glycolipids recognized by A2B5 antibody promote proliferation, migration, and clonogenicity in glioblastoma cells. Cancers (Basel) 11: 1267, 2019.

91. De la Rocha AM, Sampron N, Alonso MM and Matheu A: Role of SOX family of transcription factors in central nervous system tumors. Am J Cancer Res 4: 312-324, 2014.

92. Weathers SP, Penas-Prado M, Pei BL, Ling X, Kassab C, Banerjee P, Bdiwi M, Shaim H, Alsuliman A, Shanley M, et al: Glioblastoma-mediated immune dysfunction limits CMV-specific T cells and therapeutic responses: Results from a phase I/II trial. Clin Cancer Res 26: 3565-3577, 2020.

93. De Haan P, Van Diemen FR and Toscano MG: Viral gene delivery vectors: The next generation medicines for immune-related diseases Hum Vaccin Immunother 17: 14-21, 2021.

94. Wang JL, Scheitler KM, Wenger NM and Elder JB: Viral therapies for glioblastoma and high-grade gliomas in adults: A systematic review. Neurosurg Focus 50: E2, 2021.

95. Desjardins A, Gromeier M, Herndon JE II, Beaubier N, Bolognesi DP, Friedman AH, Friedman HS, McSherry F, Muscat AM, Nair S, et al: Recurrent Glioblastoma treated with Recombinant Poliovirus. N Engl J Med 379: 150-161, 2018.

96. Bhaduri A, Di Lullo E, Jung D, Müller S, Crouch EE, Espinosa CS, Ozawa T, Alvarado B, Spatazza J, Cadwell CR, et al: Outer Radial Glia-like cancer stem cells contribute to heterogeneity of glioblastoma. Cell Stem Cell 26: 48-63.e6, 2020. 
97. Patel AP, Tirosh I, Trombetta JJ, Shalek AK, Gillespie SM, Wakimoto H, Cahill DP, Nahed BV, Curry WT, Martuza RL, et al: Single-cell RNA-seq highlights intratumoral heterogeneity in primary glioblastoma. Science 344: 1396-1401, 2014.

98. Xu HS, Qin XL, Zong HL, He XG and Cao L: Cancer stem cell markers in glioblastoma-an update. Eur Rev Med Pharmacol Sci 21: 3207-3211, 2017.

99. Ludwig K and Kornblum HI: Molecular markers in glioma. J Neurooncol 134: 505-512, 2017.

100. Pointer KB, Clark PA, Zorniak M, Alrfaei BM and Kuo JS: Glioblastoma cancer stem cells: Biomarker and therapeutic advances. Neurochem Int 71: 1-7, 2014

101. Ahmed SI, Javed G, Laghari AA, Bareeqa SB, Farrukh S, Zahid S, Samar SS and Aziz K: CD133 expression in glioblastoma multiforme: A literature review. Cureus 10: e3439, 2018.

102. Beier CP and Beier D: CD133 negative cancer stem cells in glioblastoma. Front Biosci (Elite Ed) 3: 701-710, 2011.

103. Colwell N, Larion M, Giles AJ, Seldomridge AN, Sizdahkhani S, Gilbert MR and Park DM: Hypoxia in the glioblastoma microenvironment: Shaping the phenotype of cancer stem-like cells. Neuro Oncol 19: 887-896, 2017

104. Bryukhovetskiy A, Shevchenko V, Kovalev S, Chekhonin V, Baklaushev V, Bryukhovetskiy I and Zhukova M: To the novel paradigm of proteome-based cell therapy of tumors: Through comparative proteome mapping of tumor stem cells and tissue-specific stem cells of humans. Cell Transplant 23 (Suppl 1): S151-S170, 2014.

105. Bryukhovetskiy I, Shevchenko V, Arnotskaya N, Kushnir T, Pak O, Victor Z, Zaitsev S, Khotimchenko Y, Bryukhovetskiy A, Sharma A and Sharma HS: Transforming growth factor- $\beta$ mimics the key proteome properties of CD133-differentiated and $\mathrm{CD}_{133^{+}}$cancer stem cells in glioblastoma. Int Rev Neurobiol 151: 219-242, 2020

106. Holladay FP, Heitz-Turner T, Bayer WL and Wood GW: Autologous tumor cell vaccination combined with adoptive cellular immunotherapy in patients with grade III/IV astrocytoma. J Neurooncol 27: 179-189, 1996.

107. Wood GW, Holladay FP, Turner T, Wang YY and Chiga M A pilot study of autologous cancer cell vaccination and cellular immunotherapy using anti-CD3 stimulated lymphocytes in patients with recurrent grade III/IV astrocytoma. J Neurooncol 48: 113-120, 2000.

108. Mitchell DA, Sayour EJ, Reap E, Schmittling R, DeLeon G, Norberg P, Desjardins A, Friedman AH, Friedman HS, Archer G and Sampson JH: Severe adverse immunologic reaction in a patient with glioblastoma receiving autologous dendritic cell vaccines combined with GM-CSF and dose-intensified temozolomide. Cancer Immunol Res 3: 320-325, 2015.

109. Brown CE, Alizadeh D, Starr R, Weng L, Wagner JR, Naranjo A, Ostberg JR, Blanchard MS, Kilpatrick J, Simpson J, et al: Regression of glioblastoma after chimeric antigen receptor T-cell therapy. N Engl J Med 375: 2561-2569, 2016.

110. Babar Khan M, Chakraborty S and Boockvar JA: Use of chimeric antigen receptor $\mathrm{T}$ cells as a potential therapeutic for glioblastoma. Neurosurgery 80: N33-N34, 2017.

111. Land CA, Musich PR, Haydar D, Krenciute G and Xie Q: Chimeric antigen receptor T-cell therapy in glioblastoma: Charging the T cells to fight. J Transl Med 18: 428, 2020.

112. Shen SH, Woroniecka K, Barbour AB, Fecci PE, Sanchez-Perez L and Sampson JH: CAR T cells and checkpoint inhibition for the treatment of glioblastoma. Expert Opin Biol Ther 20: 579-591, 2020

113. Salinas RD, Durgin JS and O'Rourke DM: Potential of glioblastoma-targeted chimeric antigen receptor (CAR) T-cell therapy. CNS Drugs 34: 127-145, 2020.

114. Bielamowicz K, Fousek K, Byrd TT, Samaha H, Mukherjee M Aware N, Wu MF, Orange JS, Sumazin P, Man TK, et al: Trivalent CAR T cells overcome interpatient antigenic variability in glioblastoma. Neuro Oncol 20: 506-518, 2018.

115. Neagu MR and Reardon DA: Rindopepimut vaccine and bevacizumab combination therapy: Improving survival rates in relapsed glioblastoma patients? Immunotherapy 7: 603-606, 2015

116. Weller M, Butowski N, Tran DD, Recht LD, Lim M, Hirte H, Ashby L, Mechtler L, Goldlust SA, Iwamoto F, et al: Rindopepimut with temozolomide for patients with newly diagnosed, EGFRvIII-expressing glioblastoma (ACT IV): A randomised, double-blind, international phase 3 trial. Lancet Oncol 18: 1373-1385, 2017
117. Elsamadicy AA, Chongsathidkiet P, Desai R, Woroniecka K, Farber SH, Fecci PE and Sampson JH: Prospect of rindopepimut in the treatment of glioblastoma. Expert Opin Biol Ther 17: 507-513, 2017.

118. Gerstner ER: ACT IV: The final act for rindopepimut? Lancet Oncol 18: 1294-1296, 2017.

119. Parney IF, Chang LJ, Farr-Jones MA, Hao C, Smylie M and Petruk KC: Technical hurdles in a pilot clinical trial of combined B7-2 and GM-CSF immunogene therapy for glioblastomas and melanomas. J Neurooncol 78: 71-80, 2006.

120. Zaitsev S, Sharma HS, Sharma A, Manzhulo I, Polevshchikov A, Kudriavtsev I, Khotimchenko Y, Pak O, Bryukhovetskiy A and Bryukhovetskiy I: Pro-inflammatory modification of cancer cells microsurroundings increases the survival rates for rats with low differentiated malignant glioma of brain. Int Rev Neurobiol 151: 253-279, 2020.

121. Vik-Mo EO, Nyakas M, Mikkelsen BV, Moe MC, Due-Tønnesen P, Suso EM, Sæbøe-Larssen S, Sandberg C, Brinchmann JE, Helseth E, et al: Therapeutic vaccination against autologous cancer stem cells with mRNA-transfected dendritic cells in patients with glioblastoma. Cancer Immunol Immunother 62: 1499-509, 2013.

122. Thomas AA, Fisher JL, Ernstoff MS and Fadul CE: Vaccine-based immunotherapy for glioblastoma. CNS Oncol 2 331-349, 2013

123. Cuoco JA, Benko MJ, Busch CM, Rogers CM, Prickett JT and Marvin EA: Vaccine-Based immunotherapeutics for the treatment of glioblastoma: Advances, challenges, and future perspectives. World Neurosurg 120: 302-315, 2018.

124. Lee YS and Radford KJ: The role of dendritic cells in cancer. Int Rev Cell Mol Biol 348: 123-178, 2019.

125. Reardon DA and Mitchell DA: The development of dendritic cell vaccine-based immunotherapies for glioblastoma. Semin Immunopathol 39: 225-239, 2017.

126. Chang CN, Huang YC, Yang DM, Kikuta K, Wei KJ, Kubota T and Yang WK: A phase I/II clinical trial investigating the adverse and therapeutic effects of a postoperative autologous dendritic cell tumor vaccine in patients with malignant glioma. J Clin Neurosci 18: 1048-1054, 2011.

127. Bogdahn U, Hau P, Stockhammer G, Venkataramana NK, Mahapatra AK, Suri A, Balasubramaniam A, Nair S, Oliushine V, Parfenov V, et al: Targeted therapy for high-grade glioma with the TGF- $\beta 2$ inhibitor trabedersen: Results of a randomized and controlled phase IIb study. Neuro Oncol 13: 132-142, 2011.

128. Wick A, Desjardins A, Suarez C, Forsyth P, Gueorguieva I, Burkholder T, Cleverly AL, Estrem ST, Wang S, Lahn MM, et al: Phase $1 b / 2$ a study of galunisertib, a small molecule inhibitor of transforming growth factor-beta receptor I, in combination with standard temozolomide-based radiochemotherapy in patients with newly diagnosed malignant glioma. Invest New Drugs 38: $1570-1579,2020$

129. Birch JL, Coull BJ, Spender LC, Watt C, Willison A, Syed N, Chalmers AJ, Hossain-Ibrahim MK and Inman GJ: Multifaceted transforming growth factor-beta (TGFbeta) signalling in glioblastoma Cell Signal 72: 109638, 2020.

130. Cannarile MA, Weisser M, Jacob W, Jegg AM, Ries CH and Rüttinger D: Colony-stimulating factor 1 receptor (CSF1R) inhibitors in cancer therapy. J Immunother Cancer 5: 53, 2017.

131. Akkari L, Bowman RL, Tessier J, Klemm F, Handgraaf SM, de Groot M, Quail DF, Tillard L, Gadiot J, Huse JT, et al: Dynamic changes in glioma macrophage populations after radiotherapy reveal CSF-1R inhibition as a strategy to overcome resistance. Sci Transl Med 12: eaaw7843, 2020.

132. Wherry EJ: T cell exhaustion. Nat Immunol 12: 492-499, 2011.

133. Ando M, Ito M, Srirat T, Kondo T and Yoshimura A: Memory T cell, exhaustion, and tumor immunity. Immunol Med 43: 1-9, 2020.

134. Mohme M, Schliffke S, Maire CL, Rünger A, Glau L, Mende KC, Matschke J, Gehbauer C, Akyüz N, Zapf S, et al: Immunophenotyping of newly diagnosed and recurrent glioblastoma defines distinct immune exhaustion profiles in peripheral and tumor-infiltrating lymphocytes. Clin Cancer Res 24: 4187-4200, 2018.

135. Litak J, Mazurek M, Grochowski C, Kamieniak P and Roliński J: PD-L1/PD-1 axis in glioblastoma multiforme. Int J Mol Sci 20 $5347,2019$.

136. Bloch O, Crane CA, Kaur R, Safaee M, Rutkowski MJ and Parsa AT: Gliomas promote immunosuppression through induction of B7-H1 expression in tumor-associated macrophages. Clin Cancer Res 19: 3165-3175, 2013. 
137. Schalper KA, Rodriguez-Ruiz ME, Diez-Valle R, López-Janeiro A, Porciuncula A, Idoate MA, Inogés S, de Andrea C, López-Diaz de Cerio A, Tejada S, et al: Neoadjuvant nivolumab modifies the tumor immune microenvironment in resectable glioblastoma. Nat Med 25: 470-476, 2019.

138. Wang X, Guo G, Guan H, Yu Y, Lu J and Yu J: Challenges and potential of PD-1/PD-L1 checkpoint blockade immunotherapy for glioblastoma. J Exp Clin Cancer Res 38: 87, 2019.

139. Prionisti I, Bühler LH, Walker PR and Jolivet RB: Harnessing Microglia and macrophages for the treatment of glioblastoma. Front Pharmacol 10: 506, 2019.

140. Di Tacchio M, Macas J, Weissenberger J, Sommer K, Bähr O, Steinbach JP, Senft C, Seifert V, Glas M, Herrlinger U, et al: Tumor vessel normalization, immunostimulatory reprogramming, and improved survival in glioblastoma with combined inhibition of PD-1, Angiopoietin-2, and VEGF. Cancer Immunol Res 7: 1910-1927, 2019

141. Kim MM, Umemura Y and Leung D: Bevacizumab and glioblastoma: Past, present, and future directions. Cancer J 24: 180-186, 2018

142. Reardon DA, Brandes AA, Omuro A, Mulholland P, Lim M, Wick A, Baehring J, Ahluwalia MS, Roth P, Bähr O, et al: Effect of nivolumab vs. bevacizumab in patients with recurrent glioblastoma: The CheckMate 143 Phase 3 randomized clinical trial. JAMA Oncol 6: 1003-1010, 2020.

143. Chen C, Zuo W, Yang P and Zhang Y: Anti-PD-1, anti-VEGF, and temozolomide therapy in a patient with recurrent glioblastoma: A case report. J Int Med Res 48: 300060520951395, 2020

144. Kong Z, Wang Y and Ma W: Vaccination in the immunotherapy of glioblastoma. Hum Vaccin Immunother 14: 255-268, 2018.

145. De Felice F, Pranno N, Marampon F, Musio D, Salducci M, Polimeni A and Tombolini V: Immune check-point in glioblastoma multiforme. Crit Rev Oncol Hematol 138: 60-69, 2019.

146. Di Giacomo AM, Valente M, Covre A, Danielli R and Maio M: Immunotherapy targeting immune check-point(s) in brain metastases. Cytokine Growth Factor Rev 36: 33-38, 2017.

147. De Felice F, Musio D, Cassese R, Gravina GL and Tombolini V: New approaches in glioblastoma multiforme: The potential role of immune-check point inhibitors. Curr Cancer Drug Targets 17: 282-289, 2017.

148. Yang M, Oh IY, Mahanty A, Jin WL and Yoo JS: Immunotherapy for glioblastoma: Current state, challenges, and future perspectives. Cancers (Basel) 12: 2334, 2020.

149. Blumenthal DT, Gorlia T, Gilbert MR, Kim MM, Burt Nabors L, Mason WP, Hegi ME, Zhang P, Golfinopoulos V, Perry JR, et al: Is more better? The impact of extended adjuvant temozolomide in newly diagnosed glioblastoma: A secondary analysis of EORTC and NRG Oncology/RTOG. Neuro Oncol 19: 1119-1126, 2017.
150. Bryukhovetskiy I, Bryukhovetskiy A, Khotimchenko Y and Mischenko P: Novel cellular and post-genomic technologies in the treatment of glioblastoma multiforme (Review). Oncol Rep 35: 639-648, 2016

151. Chen $Z$ and Hambardzumyan D: Immune microenvironment in glioblastoma subtypes. Front Immunol 9: 1004, 2018.

152. Bryukhovetskiy IS, Dyuizen IV, Shevchenko VE, Bryukhovetskiy AS, Mischenko PV, Milkina EV and Khotimchenko YS: Hematopoietic stem cells as a tool for the treatment of glioblastoma multiforme. Mol Med Rep 14: 4511-4520, 2016.

153. Bryukhovetskiy IS, Mischenko PV, Tolok EV, Zaitcev SV, Khotimchenko YS and Bryukhovetskiy AS: Directional migration of adult hematopoeitic progenitors to C6 glioma in vitro. Oncol Lett 9: 1839-1844, 2015.

154. Milkina E, Ponomarenko A, Korneyko M, Lyakhova I, Zayats Y, Zaitsev S, Mischenko P, Eliseikina M, Khotimchenko Y, Shevchenko V, et al: Interaction of hematopoietic CD $34^{+} \mathrm{CD} 45^{+}$ stem cells and cancer cells stimulated by TGF- $\beta 1$ in a model of glioblastoma in vitro. Oncol Rep 40: 2595-2607, 2018.

155. Calvi LM and Link DC: The hematopoietic stem cell niche in homeostasis and disease. Blood 126: 2443-2451, 2015.

156. Bryukhovetskiy AS, Grivtsova LY and Sharma HS: Is the ALS a motor neuron disease or a hematopoietic stem cell disease? Prog Brain Res 258: 381-396, 2020.

157. de Laval B, Maurizio J, Kandalla PK, Brisou G, Simonnet L, Huber C, Gimenez G, Matcovitch-Natan O, Reinhardt S, David $\mathrm{E}$, et al: $\mathrm{C} / \mathrm{EBP} \beta$-dependent epigenetic memory induces trained immunity in hematopoietic stem cells. Cell Stem Cell 26: 657-674.e8, 2020.

158. Yanada M, Takami A, Mizuno S, Mori J, Chou T, Usuki K, Uchiyama H, Amano I, Fujii S, Miyamoto T, et al: Autologous hematopoietic cell transplantation for acute myeloid leukemia in adults: 25 years of experience in Japan. Int J Hematol 111: 93-102, 2020.

159. Arora S, Majhail NS and Liu H: Hematopoietic progenitor cell mobilization for autologous stem cell transplantation in multiple myeloma in contemporary Era. Clin Lymphoma Myeloma Leuk 19: 200-205, 2019.

This work is licensed under a Creative Commons Attribution-NonCommercial-NoDerivatives 4.0 International (CC BY-NC-ND 4.0) License. 